\title{
Vrede as 'n onontginde navorsingstema in die Nuwe-Testamentiese Wetenskap
}

\begin{tabular}{|c|c|}
\hline $\begin{array}{l}\text { Author: } \\
\text { Pieter G.R. de }\end{array}$ & Villiers ${ }^{1}$ \\
\hline $\begin{array}{l}\text { Affiliation: } \\
{ }^{1} \text { Department } \\
\text { Testament, U } \\
\text { Free State, So }\end{array}$ & $\begin{array}{l}\text { Old and New } \\
\text { iversity of the } \\
\text { uth Africa }\end{array}$ \\
\hline $\begin{array}{l}\text { Note: } \\
\text { This article is } \\
\text { version of a } p \\
\text { presented at } \\
\text { OT Nederland } \\
\text { Vlaamse Konf } \\
\text { Faculty of The } \\
\text { North-West U } \\
\text { Potchefstroon } \\
\text { January } 2015 \\
\text { of author give } \\
\text { for indexing } p\end{array}$ & $\begin{array}{l}\text { reworked } \\
\text { aper } \\
\text { he NAVNUT/ } \\
\text { s-Afrikaans- } \\
\text { erensie, } \\
\text { ology of the } \\
\text { niversity, } \\
\text {, 20-22 } \\
\text { Full first name } \\
\text { n in the citation } \\
\text { urposes. }\end{array}$ \\
\hline $\begin{array}{l}\text { Corresponde } \\
\text { Pieter de Villi }\end{array}$ & $\begin{array}{l}\text { ice to: } \\
\text { ers }\end{array}$ \\
\hline $\begin{array}{l}\text { Email: } \\
\text { pgdevilliers@ }\end{array}$ & nweb.co.za \\
\hline $\begin{array}{l}\text { Postal addres } \\
109 \text { La Cleme } \\
\text { Stellenbosch } \\
\text { South Africa }\end{array}$ & $\begin{array}{l}\text { s: } \\
\text { nce, } \\
600,\end{array}$ \\
\hline $\begin{array}{l}\text { Dates: } \\
\text { Received: } 13 \\
\text { Accepted: } 10 \\
\text { Published: } 11\end{array}$ & $\begin{array}{l}\text { Apr. } 2015 \\
\text { June } 2015 \\
\text { Sept. } 2015\end{array}$ \\
\hline $\begin{array}{l}\text { How to cite th } \\
\text { De Villiers, Pie } \\
\text { 'Vrede as 'n o } \\
\text { navorsingsten } \\
\text { Testamentiese } \\
\text { HTS Teologies } \\
\text { Theological St } \\
\text { Art. \#3001, } 9 \\
\text { dx.doi.org/10 } \\
\text { v71i1.3001 }\end{array}$ & $\begin{array}{l}\text { is article: } \\
\text { ter G.R., 2015, } \\
\text { nontginde } \\
\text { la in die Nuwe- } \\
\text { Wetenskap', } \\
\text { e Studies/ } \\
\text { udies 71(1), } \\
\text { oages. http:// } \\
\text { 4102/hts. }\end{array}$ \\
\hline $\begin{array}{l}\text { Copyright: } \\
\text { (C) 2015. The } \\
\text { Licensee: AOS } \\
\text { OpenJournals } \\
\text { licensed unde } \\
\text { Commons Att } \\
\text { License. }\end{array}$ & $\begin{array}{l}\text { Authors. } \\
\text { IS } \\
\text { This work is } \\
r \text { the Creative } \\
\text { ibution }\end{array}$ \\
\hline Read online: & \\
\hline 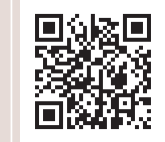 & $\begin{array}{l}\text { Scan this QR } \\
\text { code with your } \\
\text { smart phone or } \\
\text { mobile device } \\
\text { to read online. }\end{array}$ \\
\hline
\end{tabular}

Peace as research theme in New Testament studies. This research article investigates peace as an underdeveloped theme in New Testament studies. Its first part documents this situation by analysing the role of the Bible and biblical research in the extensive social, theological and ecclesiastical discourse on war, violence and peace. In following parts the article investigates some recent literature in New Testament studies on peace and evaluates its place in the discipline as representing a reversal of the limited attention to peace and as illustration of the need for more research. In a fourth part the reasons why peace as a theme is relatively underdeveloped, are spelled out, whilst a fifth section investigates the need for and challenges to exploring peace adequately within New Testament Studies.

\section{Inleiding}

\section{Vrede as tema in die teologie en kerk}

Dit sou op die oog af oordrewe lyk om vrede as 'n onontginde tema in die Nuwe-Testamentiese Wetenskap te beskryf. Daar is immers in talle teologiese en kerklike kontekste besprekings van sulke bekende vredestekste in die Bybel soos, om maar net een voorbeeld te noem, die bergrede van Jesus. ${ }^{1}$

By nadere ondersoek is so 'n stelling egter nie ondenkbaar nie. 'n Oorsig oor besprekings in kerklike en teologiese literatuur oor die konfigurasie van oorlog, geweld en vrede, ${ }^{2}$ sal spoedig uitwys hoe min Nuwe-Testamentiese vakliteratuur daarin gelys word.

'n Voorbeeld hiervan is die goed gedokumenteerde analise van oorlog en vrede in die besinning van Thielicke, die bekende Duitse etikus (1966:557-560). ${ }^{3}$ In sy uitvoerige bespreking ontbreek Nuwe-Testamentiese vakliteratuur oor die tema feitlik geheel en al. Op dieselfde wyse is daar, byna twee dekades later, in die invloedryke werk van Hauerwas (1983:72-95) 'n hele hoofstuk oor Jesus se oprigting van die vredeskoninkryk, maar dan slegs met verwysings na minder as vyf Nuwe-Testamentiese publikasies. Nog 'n ander voorbeeld is te vind in die uitgebreide debatte oor pasifisme wat sedert die vorige eeu die tema van vrede heel pertinent op die kerklike en teologiese agenda geplaas het, met besondere implikasies vir sosio-politieke realiteite. Binne die Nuwe Testament as dissipline is daar egter min akademiese publikasies oor die Bybelse inhoud wat ten opsigte van pasifisme in hierdie wydverspreide sosiale diskoers ter sprake gebring is.

'n Verdere voorbeeld is die afwesigheid van Nuwe-Testamentiese navorsing ten opsigte van niegewelddadige of vredesbewegings ${ }^{4}$ waarin die Bybelse inhoud dikwels 'n groot rol speel. ${ }^{5}$

1.Vir die belangrike rol van Bybelse tekste, kyk Gros $(1994: 12$, n. 26); Chatfield $(1996: 6,8)$. Vir ander Bybelse materiaal, kyk Loewen (1994:17-25); Weaver en Biesecker-Mast (2003).

2.Oorlog is ' $n$ veel besproke onderwerp in die teologiese en kerklike diskoers - tot so ' $n$ mate dat die toonaangewende Duitse etikus Thielicke reeds vyftg jaar gelede opgemerk het (1966:586) dat publikasies daaroor feitlik onoorsigtelik geword het. Kyk ook Van Wyk (1984:12, voetnoot 5). Die omvang van oorlogsnavorsing word origens duidelik uit die oprigting van die Journal of Religion and Violence in 2013 as ' $n$ eie tydskrif vir die gebied. Die Comparative Approaches to Religion and Violence Group in die American Academy of Religion en die Violence and Representations of Violence Among Jews and Christians Section van die Society of Biblical Literature is besonder aktiewe groepe wat gereeld verskeie voordragte in hul baie sessies aanbied. Vir navorsing oor geweld in die Nuwe Testament, kyk De Villiers (2008a). Die oorlogsdiskoers is in die laaste dekade of twee ingebed in 'n groter gesprek oor baie ander vorme van geweld (soos bv. verbale, strukturele en gendergeweld). Hierdie massiewe belangstelling in oorlog maak dit selfs meer opmerklik dat vrede nie naasteby soveel aandag kry nie. Dit is ook vreemd, gegewe die feit dat oorlog sekerlik bedink behoort te word in terme van 'n situasie wat nie deur oorlog of geweld gekenmerk word nie.

3. Kyk byvoorbeeld hoe die Bybelse opmerkings na vore kom in die werk van Thielicke (1966:57) wanneer hy skryf: 'Vom Ende, nämlich vom messianische Reich, erwarten die Propheten eine Zeit des Friedens, in der die Schwerter in Pflugscharen verwandelt werden und die Erde von Gerechtigkeit und Frieden erfüllt ist'. [Vir die einde, d.w.s. die Messiaanse Ryk, verwag die profete ' $n$ tyd van vrede waarin swaarde in ploegskare verander word en die aarde met geregtigheid en vrede gevul is] en sy bespreking (1966:560) oor hoe die Nuwe Testament vrede eerder as oorlog aanprys.

4.Kyk Weaver en Biesecker-Mast (2003) vir verskeie hoofstukke waarin boeiende aspekte van niegewelddadigheid as tema en wêreldbeskoulike beweging bespreek word en Chatfield (1996:9) vir'n bespreking van Gandhi en King se invloed in dié verband. Ook is niegewelddadigheid 'n omstrede begrip wat kritiek uitlok. Kyk Brownlee (2013) vir'n oorsig oor die tema en die kritiek daarop. Stassen and Westmoreland-White (2003:27) noem as voorbeeld van die omstredenheid die burgerregtebeweging in Amerika se gewelddadige aksies.

5.Kyk Chatfield (1996:12) en Stassen and Westmoreland-White (2003) vir voorbeeld van sulke vredesbewegings. 
Prominente teoloë ${ }^{6}$ soos, onder andere, Brunner, Gollwitzer, Althaus, Kuitert, die Niebuhrs, Arendt, ${ }^{7}$ Hauerwas en Day, ${ }^{8}$ en snykant-navorsing deur vredesteoloë soos Volf, Yoder en Weaver wat die gesprek oor vrede tot in die kern van die teologiese debat gevoer het met, onder andere, kritiese besprekings van die gewelddadige karakter van die versoeningsleer, het dit meestal gedoen sonder veel verwysing na Nuwe-Testamentiese navorsing. Weer eens soek 'n mens byna vergeefs in dié refleksie in en oor hierdie bewegings na akademiese besprekings oor vrede vanuit die Nuwe-Testamentiese Wetenskap.

Met die sterk uitbreiding van die vredesgesprek in die tweede helfte van die twintigste eeu, was daar tog wel buite die Nuwe-Testamentiese Wetenskap gevalle waar belangrike instansies aktief die medewerking van Bybelwetenskaplikes in hul besinning oor vrede gesoek het. Gros (1994:10) skryf byvoorbeeld dat Bybelwetenskaplikes met gebruikmaking van die mees gevorderde navorsingsmetodes meegewerk het aan vredesgesprekke in die kringe van die Wêreldraad van Kerke. Hierdie gesprekke was egter steeds buite die NuweTestamentiese Wetenskap gelokaliseer en het, interessant genoeg, nie gelei tot akademiese publikasies oor vrede binne die Nuwe-Testamentiese Wetenskap self nie.

Die lakune is veral opvallend in die lig van verwysings na die Bybelse inhoud in hierdie teologiese en kerklike gesprek oor oorlog en vrede. Vrede as tema binne die NuweTestamentiese Wetenskap kan dus tereg 'n onontginde tema genoem word. Dit is, trouens, eintlik ironies dat die teologie in die algemeen soveel aandag aan vrede geskenk het, soos telkens deur sommige navorsers uitgewys is, ${ }^{9}$ terwyl daar min BybelWetenskaplike materiaal vir die ander teologiese dissiplines is om op terug te val (kyk ook Luz et al. 1981:10-11).

\section{Vrede en die Bybelwetenskappe}

Dit is verder ook verhelderend om die vredesgesprek met besinning oor oorlog te vergelyk. In die afgelope dekade toon 'n toenemende getal publikasies dat daar in die NuweTestamentiese Wetenskap wel'n merkbare ommekeer is in die ondersoek na oorlog en geweld. Thielicke se opmerking (sien hierbo) oor die ongekende omvang van oorlogsnavorsing in die teologie is tans byna ook al geldig vir geweldsnavorsing in die Bybelwetenskappe. Die toename in hierdie navorsing is opvallend, gegewe die opmerking van Desjardins dat die diskussie oor geweld in die Bybel nog nie op dreef gekom het nie. Naas, volgens hom, die Nuwe-Testamentiese boodskap

6.Van wyk (1984) bevat uitvoerige verwysings na prominente deelnemers aan die teologiese debat oor vrede uit verskillende tradisies.

7.Kyk Bernstein (2013) vir 'n sinvolle bespreking van Arendt se denke oor geweld of niegewelddadigheid.

8.Kyk Klejment and Roberts (1996) vir die merkwaardige invloed van Day in die vestiging van pasifisme in ' $n$ Noord-Amerikaanse Rooms-Katolieke konteks, maar vergelyk ook die inligting oor pasifisme binne die Protestantse geloofsgemeenskappe (bv. 1996:6).

9.Kyk Gros (1994), asook Brenneman and Ollenburger (2013:x). 'n Uitsondering is sommige van die vredeskerke soos die Kwakers, die Broeders (Brethren) en vera die Mennoniete. oor vrede ${ }^{10}$ is daar teksgedeeltes wat geweld bevorder en soms net so sterk soos die vredesboodskap is. 'The violencepromoting side, though, is equally strong: it also disturbs me, all the more so because I find it rarely discussed in academic and non-academic circles' ${ }^{11}$ Die situasie is tans drasties anders met vele werke in Nuwe-Testamentiese kringe oor geweld. Dit is ironies dat juis Desjardins (1997:1-61) byvoorbeeld een van weiniges is wat ook aandag aan vrede bestee. ' $n$ Ander uitsondering is die werk van Luz et al. (1981), wat die reël verder bevestig.

Hierdie toename in geweldsnavorsing skep die verwagting dat vrede as studieveld tog ook mettertyd tot sy reg sal kom, veral omdat geweld en vrede logies verband hou en mekaar wedersyds kan help verklaar. Hoe sinvol dit is om oorlog en vrede saam te bekyk, is byvoorbeeld duidelik uit 'n artikel in 'n informatiewe boek oor geweld in godsdiens, waarin Aden (2007:137-138) oor die rol van selfregverdiging in geweld skryf. (Die gedeelte bevat, trouens, die enigste verwysing na vrede in die boek. ${ }^{12}$ ) Aden merk in dié gedeelte op dat dialoog die enigste weg tot vrede is, want geweld kan volgens hom nie in die teenwoordigheid van dialoog oorleef nie. Dít, weer, veronderstel dat 'n mens deur die vrede van God bemagtig word:

The peace of God is a multifaceted reality if we take seriously both the Old and the New Testaments. It is a state of wholeness or completeness or, if it is applied to groups or nations, it is the absence of hostilities and the presence of harmonious relationships of mutual benefit and goodwill ... The peace and generosity of God free us to enter into genuine dialogue with the other person and empower us to share our lives and our destiny with each others. It marks the end of violence and the beginning of a worldwide community. (Aden 2007:137)

Juis omdat die gedeelte wys hoe sinvol dit is om oorlog en vrede saam te bespreek, val die gebrek aan verwysings na Nuwe-Testamentiese vakwetenskaplike literatuur oor vrede verder op. ${ }^{13}$

Die min aandag aan vrede in die Bybelwetenskappe het nie ongemerk verbygegaan nie. Byna 'n dekade gelede is dit met enkele ter sake voorbeelde gedokumenteer deur Swartley in sy werk oor vrede waaraan hy die veelseggende en raak titel gegee het: Covenant of peace: The missing peace in New Testament theology and ethics. Hy (2006:431-471) het byvoorbeeld opgemerk dat 25 van die bekende publikasies oor teologie en etiek nêrens aandag aan die Lukaanse geskrifte oor vrede gee nie, terwyl dit ' $n$ kwart van die Nuwe Testament uitmaak. Net een van die 25 het byvoorbeeld 'n substansiële

10.Dit is ironies dat Desjardins se uitgebreide aandag an vrede in sy boek nie soveel invloed gehad het soos sy opmerkings oor geweld daarin nie.

11.Desjardins (1997:121; kursivering toegevoeg); vergelyk verder Frankfurter (2005:141).

12.Daar is wel artikels oor die Bybel, Bybelse geweldstaal, Jesus en niegewelddadigheid in hierdie boek, maar hulle verwys nie na vrede nie. Die boek bevat ook minimale verwysings na publikasies van Nuwe-Testamentici.

13.Desjardins (1997:60-61) bied nog ' $n$ voorbeeld van hoe belangrik dit is om oorlog/ geweld en vrede saam te bespreek. Hy wys daarop dat die Nuwe-Testamentiese boodskap van vrede fundamenteel niegewelddadig is. Christene word in die Nuwe Testament nêrens tot geweld opgeroep nie, maar wel om vrede te soek en te Testament nêrens tot geweld opgeroep nie, maar wel om vrede te soek en te
maak. Hy wys ook daarop dat die vredesboodskap behels dat Christene geweld maak. Hy wys ook daarop dat die vred
wat hulle aangedoen word, aanvaar. 
bespreking gewy aan Paulus se belangrike opmerking oor die God van vrede. ${ }^{14}$

Afgesien van hierdie kwantitatiewe inligting van Swartley, is daar ook nog kwalitatiewe perspektiewe wat in ag geneem moet word. Die beperkte verwysings na en besprekings van vrede in Nuwe-Testamentiese navorsing word verder belig deur die manier waarop vrede ondersoek word. Van belang in die reeds beskeie getal navorsingspublikasies is dus nie soseer hoeveel keer nie, maar hoe vrede inhoudelik ter sprake gebring word en hoe dit as voorwerp van ondersoek met ander navorsingstemas vergelyk. In onlangse jare was daar byvoorbeeld 'n stortvloed van Nuwe-Testamentiese teologieë waarin dekade lange histories-kritiese navorsing sinvol verder gevoer, sistematies bedink en teologies uitgelê word..$^{15}$ Hierdie teologieë fokus op insigte van bepaalde corpora van Nuwe-Testamentiese skrywers en behandel dan in hulle werke temas soos sonde, bekering, geloof, regverdiging, versoening, die kerk, die nagmaal en die eindtyd. Dit sou byna vanselfsprekend wees dat vrede in sulke publikasies prominent ter sprake sou kom.

Dit is egter nie die geval nie. In sommige van hierdie teologieë word vrede byvoorbeeld in die verbygaan en bloot terloops bespreek in gedeeltes wat oor regverdiging en versoening handel. ${ }^{16}$ 'n Goeie voorbeeld hiervan is Ladd (1993:496-497) wat vrede in net twee bladsye as 'n resultaat van versoening bespreek. Van belang is sy veelseggende opmerking (Ladd 1993:496) wat direk op die bespreking volg: 'The concept of peace is a very rich, many-sided concept that cannot here be elucidated.' Die indruk word gewek dat in 'n teologie van die Nuwe Testament vrede 'n negeerbare tema en randverskynsel is. Hierdie teologieë illustreer ook hoe vrede wel aan die orde gestel word, maar meestal op 'n insidentele wyse en nooit as ' $n$ tema in eie reg nie. ${ }^{17}$

\section{'n Ommekeer?}

Daar is tekens dat daar in onlangse tye ' $n$ ommekeer aan die gebeur is. Dit is te merk aan sekere studies waaruit die belang van vrede in die interpretasie van die Nuwe Testament sterker na vore begin kom. 'n Voorbeeld hiervan is die aandag vir Jesus as vredestigter in navorsing oor die

\section{Kyk ook Stassen (2006:x).}

15.Kyk byvoorbeeld, onder andere, Hübner ([1990] 1993); Watson (1994, 1997); Marshall (2004); Hahn (2005a, 2005b); Dunn (1993) en Schnelle (2007).

16.Kyk byvoorbeeld hoe Ridderbos (1975:184) die eskatologiese pasifikasie met versoening verbind. Vir ander, kyk Swartley (2006:431-471). Hierdie band tussen vrede en versoening is belangrik, omdat dit aanwys hoe die woord 'vrede' binne ' $n$ semantiese veld funksioneer (sien verder hier onder).

17.Dit is, mutatis mutandis, waar van ander soortgelyke werke waarin die vredesboodskap van Jesus 'n gewilde verwysingspunt is, maar nooit as tema self indringend en in al sy kompleksiteite aan die orde kom nie. Kyk byvoorbeeld na die trilogie van Wink $(1984,1986,1992)$ wat gehandel het oor Jesus se geweldloosheid waarvan die kruis as die mees tekenende simbool uitgebeeld word. ' $n$ Ander voorbeeld is die kanonieke perspektief wat uitwys hoe die vredesparadys in Genesis se skeppingsverhaal en die terugkeer van die paradys in Openbaring 'n rin om die Bybelse teks vorm. Dit kry selfs groter betekenis wanneer die deurlopende om aandag aan die belangrike Bybelse kombinasie van protologie en eskatologie (onder meer in apokaliptiese tekste) in gedagte gehou word. Kyk hieroor Neville (2013), wat veel daarvan maak (met verwysing, onder meer, na Crossan). Som word die ring verbind met ' $n$ derde perspektief wat die vredesmotief vanuit ' Christologiese hoek benader, waxin dieterugkeer van die paradys in die bediening van Jesus as ' $n$ sentrale punt gefokaliseer word sodat begin, middel en einde in die teken van vrede staan. Die kanonieke benadering tot die Nuwe Testament is egte beperk sodat sulke insigte nie werklik groot invloed op die Wetenskap uitoefen nie. historiese Jesus, hoewel meestal nog in sterk kombinasie met ' $n$ studie van geweld. Dit gebeur byvoorbeeld veral in Crossan se werk (1994, 2005; sien ook Horsley 1973, 2003) waarin hy noukeurig aandag gee aan vrede as die oogmerk van die Romeinse Ryk se oorlogsvoering. Hy bespreek vrede in Romeins imperiale teologie met sy vredesbeskrywings van die keiser op muntstukke, tempels, inskripsies, asook ander belangrike inligting oor vrede as konteks (beide in die Romeinse Ryk in die algemeen en die Herodiaanse Palestina in die besonder) waarbinne en waarteenoor Jesus se alternatiewe vredesaanbod verstaan word. Teenoor die hiërargiese struktuur van Romeinse mag, poneer hy Jesus se egalitêre koninkryk van God waarin almal toegang tot God het. Vrede verkry 'n sosio-politieke kleur as 'n teenreaksie op Romeise vredesaansprake (Crossan), of wys op egalitêre verhoudinge en die afbreek van ongelykheid tussen mense. Tog word ook weer byvoorbeeld in die werke min aandag gegee aan ander ryk insigte, soos die prominente plek van vrede in die Ou Testament en die manier waarop dit vrede in die tyd van die Nuwe Testament gehelp kleur het, terwyl die verskillende opvattinge van vrede in Bybelse tekste ook nie tot hulle reg kom nie. Wright (1996:22-29), 'n bekende kritikus van die werkswyse van navorsers soos Crossan, het wel self besondere uitsprake gemaak oor Jesus as vredebrenger, maar ook by hom bly dit ' $n$ insidentele, soms selfs simplistiese gebruik van die tema. In hierdie werke is vrede, hoewel by tye ' $n$ belangrike motief, nie ' $n$ tema in eie reg nie en word dit ook nie erken as 'n komplekse, veelkantige begrip wat op uiteenlopende maniere in Bybelse tekste gebruik word nie (sien die verdere bespreking hier onder).

Al hierdie navorsingsuitsette toon dat vredesnavorsing nie deel was van die hoofstroom in Nuwe-Testamentiese navorsing nie. Die ommekeer wat aan die gebeur is, blyk daaruit dat vrede op 'n meer substansiële wyse ter sprake gebring word. Opvallend, egter, is dat dit nog nie in die hoofstroom van navorsing gebeur nie. Dit is meestal navorsing deur bepaalde geloofsgemeenskappe en hul akademiese vennote wat 'n eksistensiële belang by die vredesbeweging het. ' $n$ Voorbeeld hiervan is die gestadige, maar tog insigryke stroom van werke afkomstig vanuit 'n Mennonitiese konteks. ${ }^{18}$ Yoder se invloedryke, maar geïsoleerde werke is in onlangse tye in hierdie konteks opgevolg deur 'n stroompie van publikasies in die reeks Studies in scripture and peace, geborg deur die Institute of Mennonite Studies aan die Anabaptist Mennonite Biblical Seminary. ${ }^{19}$ Byna 'n dekade

18.Amdt (2011:9) wys daarop dat moderne lesers dikwels Bybelse materiaal vermy omdat die etiese karakter daarvan nie juis sterk na vore kom nie en Bybelse tekste soms ambigu is, en omdat Bybelse tekste nie altyd helder is oor normatiewe soms ambig
inhoude nie.

19.Dit is insiggewend om die titels in hierdie reeks te lees: Laura L. Brenneman en Brad D. Schantz, (eds.): Struggles for shalom: Peace and violence across the Testaments. David J. Neville: A peaceable hope: Contesting violent eschatology in New Testament narratives. Darrin W. Snyder Belousek: Atonement, justice, and peace: The message of the cross and the mission of the church. Willard M. Swartley: Covenant of peace: The missing peace in New Testament theology and ethics. Millard Lind: The sound of sheer silence and the killing state: The death penalty and the Bible. Mary $\mathrm{H}$. Schertz en Ivan Friesen (eds.): Beautiful upon the mountains: Biblical essays on mission, en Ivan Friesen (eds.). Beautiful upon the mountains. Biblical essays on mission, peace, and the reign of God. Christopher D. Marshall. Crowned with glory and honor: Human rights in the Biblical tradition. Christopher D. Marshall: Beyond retribution: A New Testament vision for justice, crime and punishment. Willard M. Swartley ed.): Violence renounced. René Girard: Biblical Studies and peacemaking. Willard M. Swartley (ed.): The love of enemy and nonretaliation in the New Testament. Percy B. Yoder en Willard M. Swartley (eds.): The meaning of peace: Biblical Studies. Ulrich Mauser: The gospel of peace: A scriptural message for today's world. 
gelede is Swartley se Covenant of peace juis ook in hierdie reeks gepubliseer (2006) en onlangs die deeglike werk van David Neville, A peaceable hope (2013) wat fokus op gewelddadige eskatologie in die Nuwe Testament. ${ }^{20}$ Die werke dui op 'n ommekeer en vestig die aandag op die belangrikheid van meer navorsing oor die tema van vrede.

\section{Oorsake van die onontginde tema van vrede}

Die oorsake van hierdie beperkte aandag aan vrede verdien nou verdere bespreking, veral omdat so 'n bespreking sal uitwys dat vrede onvermydelik 'n kerntema in NuweTestamentiese navorsing gaan word. Onder die baie moontlike oorsake, ${ }^{21}$ word net enkele heel belangrikes uitgelig.

\section{Eksterne oorsake}

Die onderbenutte tema van vrede in Bybelwetenskaplike konteks is soms 'n resultaat van die algemene vredesgesprek in die breër sosiale konteks. Wat in Nuwe-Testamentiese navorsing ontbreek, is in sommige opsigte die gevolg van (of die gebrek aan) ekterne impulse. Die omvattende sosiale vredesdiskoers betrek vele dissiplines omdat vrede' $n$ tema is met vele sosiale, politieke, ekonomiese, sielkundige, militêre en ander implikasies. In hierdie komplekse, interdissiplinêre omgewing is die geloofsperspektief en teologiese insette twee van vele ander insette. Gevolglik is min ruimte vir gevorderde Nuwe-Testamentiese navorsing oor vrede gelaat. Wat wel opval is dat die behoefte aan sulke navorsing nie in die Nuwe-Testamentiese Wetenskap uitgespreek, opgevolg of voorsien is nie.

Die beperkte ruimte is egter nie net die gevolg van die omvattende aard van die vredesgesprek nie. Dit hang ook saam met sekere negatiewe persepsies van die teologie en geloofsgemeenskappe by navorsers uit ander dissiplines. Ogletree (2003:183) wys byvoorbeeld daarop dat die kontemporêre gesprek daartoe neig om in hul etiese navorsing en aksies slegs 'n vae verband met die Christendom en die kerk te lê. Die afstandelikheid is die gevolg van wantroue in die verdelende rol wat geloofsgemeenskape (en hul uiteenlopende, dikwels botsende perspektiewe op Bybelse materiaal) speel. Sulke, veral behoudende, gemeenskappe wil nie hul verhoudinge met bepaalde belangegroepe in hul midde versteur nie. Ter wille van goeie verhoudinge met die groep, vermy hulle betrokkenheid by aksies oor omstrede sake soos burgerregte, oorlog, ekologie en kernkrag. Etici steun dus eerder op sekulêre bewegings wat groter openheid en waagmoed aan die dag lê om deel te neem aan aksies wat vernuwing en hervorming kan bewerkstellig. By sulke etici blyk daar nie veel vertroue te wees in die transformerende impak van geloofsgemeenskappe en hul formatiewe

20.Neville (2013:269-270) lys byvoorbeeld nege artikels wat hy in die bestek van drie jaar oor geweld en vrede geskryf het. Hy is ' $n$ voorbeeld van ' $n$ navorser wat as individu in die tema belangstel met sekere navorsingvoorkeure, maar sy navorsing toon ook hoeveel werk daar nog oor die tema te doene is.

21.Swartley (2006:437) noem voorbeelde hoe kerklike verbintenisse navorsing oor vrede beïnvloed. skriftradisies nie. Die gebrek aan Bybelwetenskaplike werk moet dus gedeeltelik ook gesoek word in die wyse waarop kerk, teologie en die Bybelwetenskap weens negatiewe persepsies uit die sosiale diskoers gemarginaliseer word.

\section{Interne oorsake}

Daar was egter ook interne oorsake vir die onontginde Bybelnavorsing oor vrede, wat gevind kan word in die fokuspunte in Bybelwetenskaplike navorsing. Die dekade lange belangstelling in histories-kritiese en literêre navorsing, gerig, in Ricoeriaanse terminologie, op die wêreld agter en in die Bybelse teks, het min ruimte gelaat vir aandag aan die appropriasie van die teks, en dus vir die rol daarvan in die wêreld voor die teks. Die navorsingsdoenigheid van Bybelwetenskaplikes was vir 'n lang tyd op ander temas, metodes en belangstellings gerig, juis om die kerklike greep op die Nuwe-Testamentiese Wetenskap te verbreek en om van fundamentalistiese oortuigings los te kom. Dit was 'n belangrike fase wat al heelwat vernuwing in kerk en teologie gebring het. Tog het dit veral histories kontekstuele studies as uitkomste gehad waarvan die implikasies en toepassing in kontemporêre kontekste nie in fokus was nie.

Dit is eers in onlangse jare dat daar weer 'n groter teologiese en etiese belangstelling in die tersaaklikheid van die Bybelse teks vir latere lesers na vore gekom het. Maar selfs in hierdie konteks is daar nog dikwels 'n terughoudendheid, veral weens die kompleksiteit van die dinamiek van appropriasie. Amdt (2011:6) skryf iets soortgelyks wanneer sy nadink oor die gebruik van die Ou Testament in etiese kwessies: 'The historical, literary, sociological complexities of this text have become for contemporary ethicists both the reasons and the means to distance themselves and their moral theology from this source'. En sy voeg dan by:

The contemporary ethicist inhabits a world that is selfconciously diverse and considers such diversity valuable - not merely a human condition but also a human good. Negotiating between the Hebrew Bible and other sources of ethical reflection, including perceptions of the world around us, often becomes complicated to the point of (unintentional) repudiation. (Amdt 2011)

Dit is egter nie net die geval met lesers wat die Ou Testament interpreteeer nie, maar sekerlik ook van Nuwe-Testamentici self dat hulle terugdeins voor die uitdagings om die brug oor die antieke wêreld van die Bybelse tekste na moderne tyd te bou. Dit geld sekerlik ook vir vrede, veral wanneer besef word hoe kompleks die verstaan daarvan in die Nuwe Testament is.

Ten nouste verbonde hieraan is die manier waarop die tersaaklikheid van die Nuwe Testament vanuit'n historiese en literêre perspektief gekonseptualiseer is. Vanuit die historieskritiese en literêre perspektief, het die lig veral op die denke van individuele Bybelskrywers in hul onderskeie tydvakke geval, met aandag aan die historiese Jesus, die sinoptiese tradisies, Paulus, Markus, Matteus, Lukas en Johannes. Tematiese studies is in hierdie kontekste geïntegreer. Die 
marginalisering van vroeëre tematiese werk is deels ook die gevolg van die argwaan by Nuwe-Testamentici teenoor dogmatiese eksegese met sy kenmerkende tematiese benadering. Waar daar wel aandag in sulke teologieë aan sekere temas gegee is, is dit veral aan sekere kernbegrippe soos versoening en regverdigmaking, eerder as aan temas soos geweld en vrede.

In 'n sekere $\sin$ is die aanname van navorsers betreffende die sogenaamde belangrikheid van vrede, ironies genoeg, 'n rede waarom die tema onontgin is. Vrede word dan dikwels as ' $n$ vanselfsprekende veronderstelling of uitgangspunt in NuweTestamentiese tekste beskou wat nie verdere navorsing verg nie. Vanweë hierdie aanname dat die Nuwe Testament 'n boek van vrede is ${ }^{22}$ is die aard daarvan nie geproblematiseer nie. Dit is eers vandat die omvang van geweld in die Nuwe Testament onder die aandag gebring is dat navorsers toenemend besef dat Bybelse tekste nie summier met vrede vereenselwig moet word nie, maar soms die vrede self en selfs bedreig, asook onvrede aanstig. Die hermeneutiek van suspisie het kritiese ondersoekers voorts in staat gestel om uit te wys hoe gewelddadig die Bybel is, selfs in gewaande niegewelddadige tekste soos Openbaring. ${ }^{23}$ Die implikasies hiervan verdien om verder ondersoek te word, byvoorbeeld deur sulke vrae te vra soos hoe hierdie gewelddadigheid in Bybelse tekste te rym is met hul vredeskarakter. Watter soort vrede in Bybelgedeeltes laat soveel ruimte vir verskillende vorme van geweld, of watter soort vrede kan selfs nie sonder geweld ervaar word nie? (Sien verder hier onder.) Onlangse navorsing beklemtoon dus dat vrede nie maar net as 'n vanselfspekende veronderstelling of uitgangspunt beskou kan word nie. Ook in hierdie opsig is daar 'n ommekeer in die beskouing oor vrede as ' $n$ veronderstelling en gevolglik ' $n$ besef dat meer navorsing oor vrede nodig is. Hierbenewens is daar ook die uitdaging wat die veelvuldige vredesvoorstellinge in die Bybel bied. Vele groepe en skrywers van Nuwe-Testamentiese tekste het immers elkeen ' $n$ eie begrip van vrede. Meer navorsing is nodig om ook die verskille te ontleed en te weeg.

\section{Die nodigheid vir meer ontginning}

Daar is verskeie faktore wat wys op die noodsaaklikheid om die tema van vrede in meer diepte te ontgin deur meer spesifieke aandag aan die rol, die aard en die implikasies van vrede in Bybelse tekste te gee. Hier kan slegs 'n paar van die meer prominente faktore ondersoek word.

\section{Beskrywing ${ }^{24}$}

Juis omdat vrede as vanselfsprekend aanvaar word en dan boonop op 'n algemene, selfs vae manier gebruik word,

22.Stassen (2006:x) wat vertel hoedat hy eerder Christelike etiek as NuweTestamentiese Studies bestudeer het omdat hy gemeen het die NuweTestamentiese vredesboodskap was duidelik genoeg.

23.Kyk De Villiers and Van Henten (2013) vir die vorme van geweld in Bybelse tekste.

24. Hier word berekend die begrip 'beskrywing' in plaas van 'definisie' gebruik om die indruk te voorkom dat dit moontlik is om vrede op 'n statiese manier te omskryf. Die begrip is nodig veral om reg te laat geskied aan die dinamiese opvatting van vrede. Kyk verder hier onder. ' $n$ Veronderstelling is byvoorbeeld dat nuwe informasie en ander kontekste steeds weer sal bydrae om die verstaan van vrede informasie en ander konte pas of te verryk. is dit soveel te meer nodig om 'n werkende beskrywing vir die woord 'vrede' te bied. Die aard en inhoud daarvan kan nie sonder meer veronderstel word nie (soos in die voorbeelde hier bo uitgewys is), maar vereis kritiese analise en beskrywing.

Dit vereis in die eerste instansie dat die woord 'vrede' helder en in detail uiteengesit word. In dié opsig is daar enigsins nog sin in die tradisionele benadering wat op die begrip vrede fokus, al is dit maar ' $n$ eerste stap tot ' $n$ meer noukeurige en gedetailleerde begrip van vrede in die vele kontekste waarin dit in Nuwe-Testamentiese tekste gebruik word. 'n Eerste stap is dus om deur ' $n$ woordstudie op sekere fundamentele eienskappe van vrede te wys.

'n Standaardvoorbeeld van so 'n woordstudie is Von Rad

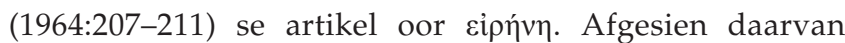
dat hierdie artikel 'n voorbeeld is van 'n nuttige oorsig oor die gebruik van vrede in Bybelse tekste en van 'n bepaalde betekenis wat as 'n werkende uitgangpunt vir verdere ondersoek kan dien, is dit opmerklik hoe 'n woordstudie soos dié reeds in 'n vroeë stadium van die ondersoek sekere kerninsigte aandui. Een so ' $n$ insig is die sterk godsdienstige karakter van vrede in Bybelse tekste. Von Rad werk konsekwent met die woorde vir vrede in Hebreeuse en Griekse Bybelse en nie-Bybelse tekste. Hulle kontrasteer byvoorbeeld die Griekse betekenis van vrede as die teenpool van oorlog en die afwesigheid van geweld, met die Ou Testament en die Septuagint se meer godsdienstige begrip van vrede as wiֹ Die Bybelse tekste toon dat vrede as heilsbegrip meer van 'n sosiale as 'n individuele karakter het: dit wys op 'n herstelde verhouding en versoening met God as 'n eskatologiese heilsgawe en gegewe vir die mensdom. ${ }^{25}$ Vrede het op 'n omvattende wyse te doen met lewe in die volle sin van die woord (Rom 8:6), nie bloot maar net as 'n toekomsuitsig nie, maar ook reeds teenwoordig in Christus as krag van God (Ef 2:14vv.). Voorts het vrede ook te doen met versoende verhoudinge met ander mense en met die mens se innerlike ervaringswêreld (Rom 15:13). ${ }^{26}$

Uit hierdie woordstudie blyk hoe vrede veral gekenmerk word deur verhoudinge wat heenwys na God se skeppende en lewegewende inisiatief. Een van die opvallende aspekte van Bybelse insigte in vrede is dat God die vredestigter, die inisiatiefnemer en die voleinder van vrede is. Vrede is inherent aan die skeppingsproses waardeur dit aan die skepping toegeken word en deur mense ontvang word as dit

25.Foerster (1964:209-210); vergelyk byvoorbeeld Lukas 2:14; $19: 42$; $19: 38$; Openbaring 12:10. Hoewel vrede in sommige Bybelse tekste met God se eindtydhandelinge verbind word, beteken dit nie dat vrede die ideale toestand vreemd aan die hede, is nie. Deur vrede eskatologies te interpreteer, word die bestaande gebroke werklikheid in sy gewelddadigheid en uitbuiting krities bekyk. Die eskatologie beteken dat God die huidige wêreld vernuwe of, as ' $n$ ander moontlikheid, 'n nuwe wêreld tot stand bring. Die huidige wêreld word daardeur as voorlopig gekwalifiseer. Hierdie kritiese funksie word vergesel van 'n positiewe funksie, in soverre as wat die eskatologie bemoedig en aanspoor om die gebroke wêreld nie wêreld nie op te gee nie (Luz et al. 1981:11; maar dit is ook die verdienste van Crossan 2005 se analise). Die hermeneutiese implikasie hiervan is dat vredestigter wel dat dit bevraagteken en beveg word.
wel

26.Foerster (1964:402-408). Die innerlike ervaring van vrede by individue is soortgelyk aan die LXX se individualiserende vertaling van שָ 
wat God wil hê. Die herskepping in Christus en die oprigting van die vredesryk in Hom, bevestig hierdie sentrale plek van vrede. Vrede is dus ingebed in die God-mens-verhouding. In hierdie verhoudingsgebeure is God as gewer ook die Vredevors. Vrede verwys na Jahwe wat vir die volk van God 'n lewe in welstand skenk sodat die vredeswerk van God voortvloei uit die Goddelike identiteit en karakter. God gee vrede om wêreld en mens te bring tot ewebeeld van God se vreedsame karakter en bestaan. ${ }^{27}$

Hierdie woordstudie bied 'n belangrike vertrekpunt vir die navorsing oor vrede, maar dit bied terselfdertyd hermeneutiese uitdagings aan vredesnavorsing. Vrede moet in die eerste plek vanuit sy belangrikste en sleuteleienskappe verstaan word. So 'n eienskap is sy konsekwente, deurslaggewende godsdienstige karakter. Vrede kan nie, soos in 'n sekulêre konteks, net negatief as die afwesigheid van geweld, die gebrek aan vyandige gevoelens vir ander of as ' $n$ innerlike belewing van rustigheid verstaan word nie. Dit is by uitstek 'n godsdienstige begrip wat in ' $n$ spiritualiteitsraamwerk ingebed is en dus 'n pregnante geestelike betekenis het. As verhouding werk dit transformatief om mense tot welstand te bring deur helende verhoudinge tot ander, tot hulself en tot hul wêreld. Hoe kompleks en omvattend hierdie impak is, word duidelik uit die band van vrede met geestelike begrippe soos geregtigheid, liefde, versoening en verlossing. ${ }^{28}$

Dit sou byvoorbeeld beteken dat vrede nie te doen het met 'n vernietigende eksklusiwiteit, met uitsluiting en voorbarige toeëiening van goddelike sanksie vir 'n mens se eie saak nie asof die ander altyd die vyandige, aggressiewe en hatige teenstander is nie. Vrede in Bybelse tekste transendeer sulke faksievormende neigings, want dit bring 'n nuwe, fiktiewe identiteit in God tot stand wat verwantskap tussen alle mense konstrueer en wat oorlog, vyandskap, faksievorming en vorme van selfbevooregting en -regverdiging bevraagteken en uitdaag. Vrede transendeer dus juis faktore wat afstand, onmin en haat tussen mense aanblaas omdat dit per slot van sake aan alle mense welstand bring. Vrede word immers as goddelike gawe van welstand aan mense gegee terwyl hulle nog vyande van God is (Rom 5:10).

Terselfdertyd bevraagteken hierdie fundamentele insig van 'n woordstudie pogings om vrede te reduseer tot 'n politieke gegewe. Die godsdienstige karakter van vrede het ongetwyfeld politieke gevolge in dié sin dat dit helende verhoudinge vra, maar dit beteken nog nie dat dit daaraan gelykgestel kan word nie.

Hierdie opmerkings wat voortvloei uit 'n woordstudie van vrede, is maar enkele voorbeelde van insigte wat verg dat die vredesmotief dieper bedink word. Die ondersoek

27. Kyk De Villiers (2008a, 2008b, 2009) vir'n meer uitgebreide bespreking van hierdie aspek aan die hand van Bybelse materiaal.

28.Dié insig word gedeeltelik opgevang wanneer navorsers soos Crossan (2005) vrede verbind met die begrip Koninkryk van God. Dit is egter ' $n$ vraag of hierdie verband verswak word deur die kontras wat hy feitlik eksklusief tussen die Ryk van God en die Romeinse Ryk teken en deur die Ou-Testamentiese invloed op die vredesbegrip te min verreken. kan besonder uitdagend word, veral in die konteks van die groter (en sekulêre) gesprek oor vrede. Dit sou kon help om vrede te artikuleer as 'n oefening in heling tussen gemeenskappe wat menslikheid as gemeenskaplike geestesgoedere besit en wat vanuit hulle identiteit as geloofsgemeenskappe geroep is tot die mede-oprigting van 'n lewe van welstand in die samelewing en om, soos God, vredestigters te wees. ${ }^{29}$

\section{Semantiek}

Die voorafgaande woordstudie is, soos aangedui, slegs 'n vertrekpunt. Daar is inherente probleme aan woordstudies. Nuwe linguïstiese insigte het immers juis getoon dat die studie van vrede nie meer tot ' $n$ woordstudie van begrippe soos gebeur, bly die vredestema op 'n deurslaggewende wyse onontgind en geabstraheerd. Nuwe linguïstiese navorsing bied verskeie nuwe perspektiewe en ondersoekmateriaal. Louw \& Nida (1988:242-248, 511-516), wat in hul leksikon op hierdie nuwere insigte bou, belig die begrip vrede vanuit verskeie semantiese velde wat vrede met verskillende woorde en begrippe konnoteer. Die semantiese velde ontsluit 'n rykdom van perspektiewe op die materiële aard van vrede. Vrede is volgens hulle deel van die semantiese veld wat verskeie 'woorde' betrek wat weer te doen het met die beskrywing van gunstige omstandighede (bv. uitkoms en verkwikking). Hulle wys daarop hoe vrede in sekere tale beteken om sonder probleme en bekommernis te wees (Luk 19:42; 1 Kor 6:11). Vrede is ook deel van die semantiese veld van houdings en emosies: vrede word ervaar wanneer iemand vry is van kommer en angs (Rom 15:13; Gal 5:22; Heb 12:11). As sodanig is vrede die teendeel van die subdomein van vrees. Vrede wys voorts op 'n situasie sonder konflik en omstredenheid (1 Tim 3:3) en hou dus verband met 'n subdomein van onmin en konflik. Voorts funksioneer vrede ook soms in die semantiese subveld van versoening as die doel en uitkoms daarvan (kyk Hand 7:26; veral Kol 1:20). Vrede hoort ook tuis in die semantiese veld wat te doen het met etiese karaktertrekke en optrede (Mark 9:50; 1 Thess 4:11; 1 Pet 3:4).

Met die semantiese analise word beklemtoon dat navorsing oor vrede nie gereduseer kan word tot 'n enkele woord vir vrede nie. Vrede word ter sprake gebring deur 'n verskeidenheid van begrippe en vertellinge, soos byvoorbeeld deur bekende woorde soos versoening, verbond, skepping en ${ }^{30}$ eksodus, maar ook deur beelde soos, onder meer, die paradys, die eskatologiese maaltyd, die boesem van Abraham en ander plastiese uitbeeldinge. ${ }^{31} \mathrm{Al}$ hierdie beelde belig aspekte

29.Weaver en Biesecker-Mast (2003:10), skryf byvoorbeeld: "Christian peacemaking and peace teaching must transcend the temptation to reduce peace to the secular art of diplomacy or the the humanistic practice of liberal tolerance, even though such skills are valuable crafts necessary for the survival of democratic and multicultural societies ...

30.Von Rad (1964:208) wys byvoorbeeld daarop dat die herstel van die paradys en die belofte van internasionale vrede (Jes 2:2a-4) en die prins van vrede (Sag 9:9-10) vrede in die omvattendste sin van die woord aandui.

31.Neville (2013) se bespreking van vrede in bybelgedeeltes bevat heelwat voorbeelde van sulke alternatiewe uitbeeldinge wat almal wys op vrede. 
van vrede as die lewe in volheid - as 'n toestand wat in verhoudinge beleef word en eties uitwerk. ${ }^{32}$

Vrede kan ook verstaan word deur kontrasterende begrippe soos oorlog, onvrede of alles wat vrede teenwerk, maar ook deur dit in 'n bepaalde diskoers en konteks te profileer. Dit gebeur byvoorbeeld in Openbaring wat vrede integreer in 'n godsdienstige, politieke en ekonomiese konfigurasie, uitgedruk met verskeie vredesmotiewe: die nuwe Jerusalem as bruid en die nuwe aarde met sy paradys (Op 19-21) is 'n leweskeppende vredesruimte wat kontrasteer met die ou Jerusalem wat op oorlogsugtige, vernietigende wyse die lewe van die Lam wreed neem en volkere uitwis (Op 11:18: '... dié wat die aarde vernietig, word vernietig'). Die stad is ook die hoer wat 'n ekonomiese magsgreep uitoefen deur die soeke na eie voordeel, korrupsie, vulgêre uitspattigheid en minagting vir ander en vir menselewe (Op 18). Die boek illustreer ook hoe die gebrek aan vrede 'n spiraalgang aan die gang sit. 'n Hoogtepunt in die beskrywing van hierdie lewensvernietigende onvrede is die beskrywing van die hoer se einde: sy word deur niemand anders as haar eie ondersteuners doodgemaak. Wie onvrede bring, lewe verwoes en haat aanblaas, word uiteindelik self die slagoffer van onvrede. Onvrede teer op onvrede. Terselfdertyd het die Messiaanse vrede, die koms van die Lam, 'n uitkringende effek. Openbaring se narratief eindig op 'n hoogtepunt wanneer die kwaad as die oorsaak van die oorlog teen die Lam en sy gevolg oorwin word. Die nuwe skepping word weer 'n stadstuin waar nuwe lewe is en almal gevoed word. Waar verwoesting ophou, word die verhouding met God herstel en word vrede as lewe in sy volheid beleef.

Die verskillende perspektiewe op vrede in Bybelse tekste wat deur hierdie semantiese benadering onthul word, bevestig aspekte van die woordstudie (van die vorige afdeling), maar ook die verhoudingskarakter van vrede. Vrede het te make met leweskeppende en vervullende verhoudinge waarin dwang, oorheersing en uitbuiting bestry word. In dié opsig soek vrede na 'n situasie van welstand waarin alle mense deel. Vrede het dus konkrete politieke dimensies. Maar die semantiese analise toon ook dat vrede te doen het met 'n innerlike disposisie. Vrede minimiseer vrees en angs, weerspieël gemoedsrus en is nou verbonde aan 'n innerlike ervaring van welstand. Deur te vergewe en te ontferm, deur te troos en gerus te stel, deur eiewaarde van ander te bevestig word vrede gesoek en moontlik gemaak.

Van belang, veral in hierdie bespreking, is dat nuwere linguïstiek kan help om vredesnavorsing sinvol verder te ontgin. Nuwe en onontginde inhoude word deur hierdie nuwere wetenskaplike ontwikkeling uitgewys as nuttige en noodsaaklike materiaal om vrede voldoende te kan verstaan.

32. Hierdie etiese dimensie kom na vore in die herhaalde oproep in Bybelse tekste to die soeke en vestiging van ' $n$ vredeskultuur. Jesus verwys na die vredemakers (Matt
5:9; Mark 9:50; kyk ook Rom 12:10; 2 Kor 13:11; 1 Tess 5:13; Heb 12:14; Ps 34:15), 5:9; Mark 9:50; kyk ook Rom 12:10; 2 Kor 13:11; 1 Tess 5:13; Heb 12:14; Ps 34:15), en bedoel daarmee mense wat soek om vrede te bevorder en tot stand te bring. $\checkmark$ rede in Bybelse tekste kry ' $n$ konkrete, transformatiewe karakter in handelinge wat in die wêreld en in menselewes plaasvind. Terwyl God die subjek is en mens die objek van God se vredesgawe, word die soeke na vrede met ander wel ook 'n duidelike etiese waarde wat tot optrede motiveer. Mense word ko-subjekte van God se vredeshandelinge.
Dit kan ook help om wanopvatting oor vrede uit die weg te ruim. Die rykdom van perspektiewe wat in semantiese analises na vore kom, help byvoorbeeld dat vrede nie tot eskatologiese (utopiese), innerlike of bloot net sosio-politieke vrede verskraal word nie (Swartley 2006:x, 439-443), of dat vrede slegs in terme van geweldloosheid bespreek word of met die afwesigheid van oorlog vereenselwig word.

Uiteindelik skep 'n semantiese analise egter nog net 'n verwysingraamwerk vir verdere navorsing. Dit wys op 'n groot klomp materiaal oor vrede wat beskikbaar is om verder ontleed te word in terme van spesifieke tekste en die kontekste waarin hulle funksioneer. Die insigte toon hoe baie en hoe kompleks vredesuitsprake in die Nuwe Testament is.

\section{Die dinamiese karakter van vrede}

Uit bogenoemde is dit verder duidelik dat selfs hierdie nuwere insigte alleen nie die begrip van vrede ten volle kan ontgin nie. Woord- en semantiese studies bied 'n vertrekpunt, maar probeer nie 'n suprahistoriese definisie van vrede verkoop nie. Vrede kan nie net in terme van semantiese inhoud en abstrakte konsepte benader word nie. Vrede is relasioneel van aard en daarom meer as net 'n 'toestand' wat deur vaste kenmerke gedefinieer kan word. Vanweë sy dinamiese en vloeibare aard, word die karakter daarvan ook bepaal deur 'n besondere situasie en konteks.

Dit is duidelik uit die verskillende vorme van vrede in Bybelse tekse. Inhoudelik kan vrede soms so verskillend verstaan word dat die opvattings daarvan mekaar selfs weerspreek. Terwyl, byvoorbeeld, profetiese tekste mense aanspoor om vrede aktief te soek, is apokaliptiese groepe veel meer terughoudend oor die moontlikheid om vrede in hul eie konteks te bevorder. Vrede in apokaliptiese tekste kom eerder deur God se ingrype as die ideaalbeeld waarheen die kerk op pad is (Luz et al. 1981:12-13). In die meeste Nuwe-Testamentiese tekste is vrede in die evangelies byvoorbeeld nader aan die profetiese opvatting as aan die apokaliptiese vredesvoorstelling van Openbaring, wat vrede as alternatief vir en toekoms van die huidige bestaanswêreld uitbeeld.

Die wyse waarop vrede gesoek word, die strukture waarin dit funksioneer, die godsdienstige inhoud wat daarmee verbind word en die gesagsverhoudinge waarin dit ingebed is, lei tot vele uiteenlopende vredesvoorstelling - nie net in die Bybel nie, maar ook in die situasie van latere lesers van Bybelse vredestekste. Vrede in die Bybel kan ingrypend verskil van vrede in latere tye. Dit kompliseer die interpretasie van vrede in die Bybel. Lesers sal die reeds komplekse aard van Bybeltekste, vanuit hul latere, ander kontekste, ook nog anders verstaan vanweë die bagasie waarmee hulle na die teks gaan.

Om die interpretasie van vrede ten volle te ontgin en dit op 'n verantwoordelike manier te doen, sal die interpretasie van tekste dus 'n kritiese selfingesteldheid vereis. Interpreteerders wat bewus is van verskeie vorme van 
vrede in die Bybel en in hul eie konteks, neem dus in hul verstaan van Bybelse tekste die afstand van hul eie tyd in ag. Dit word inderdaad heel kompleks: die oefening van appropriasie waardeur die brug van die wêreld agter en in die teks na die wêreld voor die teks oorgesteek word, verg nie alleen ' $n$ kritiese analise van Bybelse tekste nie, maar veral ook van interpreteerders, hul konteks, hul belange en die bagasie waarmee hulle tekste benader. Vrede in antieke Bybelse tekste verskil byvoorbeeld van vredesgesprekke in kontemporêre samelewings met hul ingesteldheid op demokrasie, menseregte en individuele vryheid. Die noue band tussen vrede en konteks, asook die dinamiese karakter van vrede roep dus terughoudendheid op om Bybelse tekste nie te maklik en te vinnig te approprieer in 'n latere samelewingskonteks nie. ${ }^{33}$

Die dinamiese, altyd weer wisselende aard van vrede sal veral in gesprekke van Nuwe-Testamentici met teologiese en kerklike vredesinterpretasies 'n belangrike rol speel. 'n Insig soos dié van Frankemölle (1992:205-206) dat daar geen suprahistoriese begrip van vrede in die Nuwe Testament is nie, maar net verskeie opvattings van vrede, sou een van die fundamentele punte wees in 'n gesprek. ${ }^{34}$ Dit is die soort gesprek waaraan daar 'n behoefte op vele vlakke is, want vanuit die Nuwe-Testamentiese Wetenskap is daar dikwels ' $n$ onbehae oor naïewe en maklike grepe op Bybelse inhoude wat die band met en invloed van historiese, literêre, politieke en retoriese kontekste ignoreer. Dikwels ontbreek die nodige en berekende vervreemding van Bybelse inligting in die proses van interpretasie en word die gegewens anakronisties gelees en oorgeneem. Te weinig word verder ook rekening gehou met die ideologiese belange wat in Bybelse tekste aan die werk is, maar ook met die vooroordele en die belangespel van navorsers. Uiteraard sal daar dikwels ongeduld met dié komplekse werk wees, maar die integriteit van die Bybelwetenskap vereis dat hierdie hermeneutiese proses nie gekompromitteer word nie.

Nuwe-Testamentici wat aanspraak maak daarop dat hulle Bybelse tekste interpreteer, kan dus nie volstaan met 'n vryblywende eksegetiese doenigheid nie of met 'n historiese afstandelikheid oor verskeie vredesopvattings daarin nie. Interpretasie is meer as om net inligting oor die wêreld van en in die teks mee te deel. Interpretasie behels ook appropriasie, in die sin van 'n toe-eiening van die materiaal in die wêreld voor die teks. Appropriasie veronderstel ook dat tendense en vrae van die wêreld voor die teks, die ondersoek van die antieke teks uitnooi, stuur en bepaal. Diegene wat interpreteer, is selfkrities bewus van hul eie wêreld en die invloed wat dit het op die lees en uitleg van die teks. ${ }^{35}$

\section{Kyk die opmerkings van Amdt (2011) hier bo.}

34. Hoewel daar miskien nie ' $n$ suprahistoriese begrip van vrede kan wees nie, is daar tog sekere wesenlike inhoude wat in die meeste tekste gedeel word. Een hiervan is byvoorbeeld die godsdienstige aard van Bybelse vrede wat hier bo vermeld is.

35.Ander kwessies oor die kontekstuele aard van vrede raak die verhouding tussen die Ou en Nuwe Testament. Die Ou Testament is immers'n onherroeplike deel van die konteks van die Nuwe Testament. Navorsing oor vrede in die Nuwe Testament bly onontgin waar die konteks nie verreken word nie. In hierdie verband moet besin word oor die wyse waarop die Nuwe Testament as boek van vrede (dikwels

\section{Slot}

Die artikel het uitgewys dat navorsing oor vrede'n onontginde tema in die Nuwe-Testamentiese Wetenskap is en die oorsake hiervan uitgespel. Die uitdagings om hierdie tema ten volle te ontgin, sal, onder meer, versigtige woordstudie, semantiese ondersoek en historiese, literêre, intertekstuele navorsing in ag neem. Die gesprek oor appropriasie word in hierdie opsig in terme van die wêreld agter en in die teks gevoer.

Méér is egter nodig. Volledige ontginning van vredesnavorsing sal vereis dat die Wetenskap saam met ander nadink oor die appropriasie van Bybelse insigte oor vrede in 'n kontemporêre konteks. By besinning oor die vraag hoe Nuwe-Testamentiese insigte tot konkrete vredestigting in 'n moderne, sekulêre samelewing bydra en 'n vredeskultuur kan help vestig, word eksegetiese en etiese insigte oor vrede geweeg aan die hand van ingeligte analises van huidige samelewingstrukture en die wyse waarop vrede daarin funksioneer. Die werk is van groot belang. Waar dit nie gebeur nie en belangrike temas in die Nuwe-Testamentiese Wetenskap onontgin bly, is die gevolg in die woorde van Amdt (2011):

$[T]$ he text ... pass out of critical hands and fall solely into the hands of those who read it and themselves uncritically; Christian moral theology as a critical endeavor would thus lose a crucial relationship, a crucial source. (p. 7)

Hier gaan dit nie net maar om intellektuele besinning nie, hoe belangrik dit mootlik ook al kan wees. Dit gaan ook nie maar net om Bybelse insigte oor vrede in 'n huidige bedeling 'toe te pas' nie. 'n Belangrike insig in teologiese vredesnavorsing begin uitwys dat informatiewe omgang met vredesnavorsing die partisipatoriese aard van Bybelse denke oor vrede onderwaardeer. Dit is nie genoeg om van vrede te weet of om vrede te wil bevorder nie. Vrede is 'n saak wat beleef moet word. Die verinnerliking van vrede, ook op navorsingsvlak, is 'n prekondisie vir 'n vredeskultuur.

Daar is ' $\mathrm{n}$ dringendheid aan hierdie besinning binne die Bybelwetenskappe en teologie, omdat die sekulêre konteks die teologie en kerk in hierdie saak vooruit is. Terwyl die Wêreldraad van Kerke sy Dekade teen Geweld as 'n program eers onlangs afgesluit het, het die Verenigde Volke reeds in September 1999 sy Verklaring en Program van Aksie ten opsigte van 'n Kultuur van Vrede onbestrede aanvaar en begin om jaarliks die bevordering van 'n kultuur van vrede

heel gesofistikeerd) teenoor die Ou Testament as teks van geweld geplaas word Hays (2006) byvoorbeeld, beklemtoon in sy veel gelese etiek dat die figuur van Hays (2006) byvoorbeeld, beklemtoon in sy veel gelese etiek dat die figuur van
Jesus die diepsinnigste insig in vrede bied. Die vraag is of en hoe so ' $n$ feitlik supersessonistiese siening van vrede in die tekste self gegrond is, veral wanneer in ag geneem word hoe die Ou Testament die vredesuitsprake en -simboliek in die Nuwe Testament bepaal het (bv. Jes 52:7). Dit laat ook buite rekening hoe problematies en mank aan vrede sommige uitsprake van Jesus is (selfs in die veelgeprese Bergrede). Kyk die voorbeelde in Neville (2013:22, met verwysing na Allison). Neville se eie oplossing dat die gedeeltes waarin Jesus minder vreedsaam is, is nie oortuigend nie. Dit bly problematies om, soos hy, ' $n$ veilige vredeskern uit Jesus se boodskap te distilleer. Hoewel daar opmerklike verskille is in byvoorbeeld die plek van oorlog in 'n teokratiese Israel teenoor die Nuwe-Testamentiese kerk die plek van oorlog in ' $n$ teokratiese Israel teenoor die Nuwe-Testamentiese kerk as minderheidsgroep wat nie tot oorlog opgeroep word nie, is vrede prominent in albei testamente. Daarbenewens verwys die verbondsmotief en eksodus na vrede as ' $n$ heilsgawe en as welstand van die volk, net soos die kruis in die Nuwe Testament die toegang tot die paradys verteenwoordig (Luk 21). Die besinning oo vrede moet dus rekening hou met verskeie belangrike uitsprake oor vrede in die Ou Testament, maar ook met ' $n$ bedenklike verband tussen vrede en geweld in Nuwe-Testamentiese gedeeltes wat tradisioneel as vredestigtend beskou is. 
te bedink. As deel van hierdie program word opvoeding in die stryd om vrede beklemtoon. ${ }^{36}$ Min instellings is soos die kerk en teologie in staat om so 'n opvoedingstaak te bevorder. Ook die Nuwe-Testamentiese Wetenskap het 'n rol in die taak te speel. Maar, weer eens, die teologie en kerk sal baat by kontemporêre opvoedingsideale wat daarop wys hoe belangrik dit is dat hulle wat oor vrede nadink en ander daaroor opvoed, die misterie daarvan peil en beleef.

\section{Erkenning}

Hierdienavorsing is moontlikgemaak deur die ondersteuning van die National Research Foundation (NRF). Die outeur aanvaar egter verantwoordelikheid vir die inhoud daarvan.

\section{Mededingende belange}

Die outeur verklaar dat hy geen finansiële of persoonlike verhouding(s) het wat hom op 'n voordelige of nadelige wyse in die skryf van die artikel beïnvloed het nie.

\section{Literatuurverwysings}

Aden, L.H., 2007, 'The role of self-justification in violence', in J.H. Ellens (ed.), The destructive power of religion. Violence in Judaism, Christianity, and Islam, pp. 137-138, Praeger, Westport, London.

Amdt, E., 2011, Demanding our attention: The Hebrew Bible as a source for Chrisian ethics, Eerdmans, Grand Rapids, MI.

Bernstein, R.J., 2013, Violence: Thinking without bannisters, Polity, Cambridge.

Brenneman, L. \& Ollenburger, B.C., 2013, 'Studies in peace and scripture. Series preface', in D.J. Neville (ed.), A peaceable hope. Contesting violent eschatology in New Testament narratives, Baker Academic, Grand Rapids, MI.

Brownlee, K., 2013, 'Civil disobedience', in Edward N. Zalta (ed.), The Stanford encyclopedia of philosophy (Winter 2013 Edition), viewed 01 March 2015, from: http://plato.stanford.edu/archives/win2013/entries/civil-disobedience/

Chatfield, C., 1996, 'The Catholic worker in the United States peace tradition', in A. Klejment \& N.L. Roberts (eds.), American Catholic Pacifism: The influence of Dorothy Day and the Catholic Worker Movement, pp. 1-13, Greenwood Publishing Group, Westport.

Crossan, J.D., 1994, Jesus: A revolutionary biography, HarperCollins, San Francisco, CA.

Crossan, J.D., 2005, 'The Justice of God and the peace of earth' in D.W. Musser \& D.D. Sutherland (eds.), War or words? Interreligious dialogue as an instrument of Peace, pp. 204-219, Pilgrim, Cleveland.

Desjardins, M., 1997, Peace, violence and the New Testament, the biblical seminar 46, Sheffield Academic, Sheffield.

De Villiers, Pieter G.R., 2008a, 'Hermeneutiese perspektiewe op geweld in die Nuwe Testament', HTS Teologiese Studies/Theological Studies 64(4), 1923-1951. http://dx.doi.org/10.4102/hts.v64i4.89

De Villiers, Pieter G.R., 2008b, 'Towards a spirituality of peace', Acta Theologica Supplement 11, 213-251.

De Villiers, Pieter G.R., 2009, 'Peace in the Pauline letters. A perspective on Biblical spirituality', Neotestamentica 43, 1-26.

De Villiers, Pieter G.R. \& Van Henten, J.W. 2013, Coping with violence in the New Testament, Brill, Leiden.

Dunn, J.D.G., 1993, The theology of Paul's letter to the Galatians, Cambridge University Press, Cambridge. http://dx.doi.org/10.1017/CBO9781139166201

Foerster, W., 1964, 'عipńvn', Theological Dictionary of the New Testament 2, 400-402.

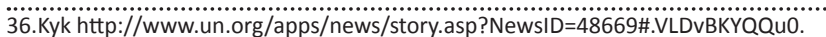

Frankemölle, H., 1992, 'Peace and sword in the New Testament', in P.B. Yoder \& W.M. Swartley (eds.), The meaning of peace. Biblical Studies, pp. 213-233, Westminster Jwart Knox, Louisville, KY.
John

Frankfurter, D., 2005, 'Violence and religious formation: An afterword', in E. Matthews \& E.L. Gibson (eds.), Violence in the New Testament, pp. 140-152, Clark, New York, NY.

Gros, J., 1994, 'Introduction', in M.E. Miller \& B.N. Gingerich (eds.), The church's peace witness, pp. 1-14, Eerdmans, Grand Rapids, MI.

Hahn, F., 2005a, Theologie des Neuen Testaments 1, Mohr-Siebeck, Tübingen.

Hahn, F., 2005b, Theologie des Neuen Testaments 2, Mohr-Siebeck, Tübingen.

Hauerwas, S., 1983, The peaceable kingdom, Notre Dame University Press, Notre Dame, IN.

Hays, R., 2006, The moral vision of the New Testament, Yale University Press, New Haven, CT.

Horsley, R., 1973, Jesus and the spiral of violence: Popular Jewish resistance in Roman Palestine, Harper \& Row, San Francisco, CA.

Horsley, R., 2003, Jesus and empire: The kingdom of God and the new world disorder, Fortress, Minneapolis, MN.

Hübner, H. [1990] 1993, Biblische Theologie des Neuen Testaments 1-2, Vandenhoeck \& Ruprecht, Göttingen.

Klejment, A. \& Roberts, A.L. (eds.), 1996, American Catholic pacifism: The influence of Dorothy Day and the Catholic Worker Movement, Greenwood Publishing Group, Westport.

Ladd, G.E., 1993, A theology of the New Testament, Eerdmans, Grand Rapids, MI.

Loewen, H.J., 1994, 'An analysis of the use of Scripture in the church's documents on peace', in M.E. Miller \& B.N. Gingerich (eds.), The church's peace witness, pp. 15-69, Eerdmans, Grand Rapids, MI.

Louw, J.P. \& Nida, E., 1988, Greek-English lexicon of the New Testament, pp. 1-2, UBS, New York, NY.

Luz, U.B., Kegler, J., Lampe, P. \& Hoffmann, P., 1981, Eschatologie und Friedenshandeln Exegetische Beiträge zur Frage christlicher Friedensverantwortung, SBS 101, KBW, Exegetische

Marshall, I.H., 2004, New Testament theology: Many witnesses, one Gospel, InterVarsity Press, Downer's Grove, IL.

Neville, D.J., 2013, A peaceable hope. Contesting violent eschatology in New Testament narratives, Baker Academic, Grand Rapids, MI.

Ogletree, T.W., 2003, The use of the Bible in Christian ethics, Westminster John Knox, Louisville, KY.

Ridderbos, H., 1975, Paul. An outline of his theology, Eerdmans, Grand Rapids, MI.

Schnelle, U., 2007, Theologie des Neuen Testaments, Vandenhoeck \& Ruprecht, Göttingen.

Stassen, G.H., 2006, 'Foreword', in W.M. Swartley (ed.), Covenant of peace. The missing peace in New Testament theology and ethics, pp. vii-xi, Eerdmans, Grand Rapids, MI.

Stassen, G.H. \& Westmoreland-White, M.L., 2003, 'Defining violence and nonviolence', in D.J. Weaver \& G. Biesecker-Mast (eds.), Teaching peace: Nonviolence and the liberal arts, pp. 17-37, Rowland \& Littlefield, Lanham.

Swartley, W.M., 2006, Covenant of Peace: The missing peace in New Testament theology and ethics, Eerdmans, Grand Rapids, MI.

Thielicke, H., 1966, Ethik des Politischen 2.2, Mohr-Siebeck, Tübingen.

Van Wyk, J.H., 1984, Etiek van vrede, Cabo, Stellenbosch.

Von Rad, G., 1964, 'Eipńvn', Theological Dictionary of the New Testament 2, 402-406.

Watson, F.B., 1994, Text, Church and World: Biblical interpretation in theological perspective, T \& T Clark, Edinburgh.

Watson, F.B., 1997, Text and truth: Redefining Biblical theology, T \& T Clark, Edinburgh.

Weaver, D.J. \& Biesecker-Mast, G., 2003, Teaching peace: Nonviolence and the liberal arts, Rowland \& Littlefield, Lanham, MD.

Wink, W., 1984, Naming the powers: The language of power in the New Testament, Fortress, Philadelphia, PA.

Wink, W., 1986, Unmasking the powers: The invisible forces that determine human existence, Fortress, Philadelphia, PA.

Wink, W., 1992, Engaging the powers: Discernment and resistance in a world of domination, Fortress, Philadelphia, PA.

Wright, N.T., 1996, 'How Jesus saw himself', Bible Review 12(3), 22-29. 